\title{
Association of Body Composition and Anthropometric Measurement with Hypertension among Workers in Universitas Ahmad Dahlan
}

\author{
Nurul Putrie Utami ${ }^{1 \star}$, Cita Eri Ayuningtyas ${ }^{1}$, Widodo Hariyono ${ }^{2}$
}

${ }^{1}$ Foodservice Industry, Faculty of Economics and Business, Universitas Ahmad Dahlan (UAD) Yogyakarta, INDONESIA
${ }^{2}$ Public Health Science, Faculty of Public Health, Universitas Ahmad Dahlan (UAD), Yogyakarta, INDONESIA
${ }^{\star}$ Corresponding Author: nurul.putrie@culinary.uad.ac.id

Citation: Utami NP, Ayuningtyas CE, Hariyono W. Association of Body Composition and Anthropometric Measurement with Hypertension among Workers in Universitas Ahmad Dahlan. Electron J Gen Med. 2020;17(5):em217. https://doi.org/10.29333/ejgm/7880

\section{ARTICLE INFO}

Received: 6 Feb. 2020

Accepted: 8 Mar. 2020

\begin{abstract}
Purpose: This study aims to investigate the relationship between anthropometric and body composition measurement with the risk of hypertension among office workers.
\end{abstract}

Methodology: This study was a cross-sectional study in office workers population in Universitas Ahmad Dahlan. The subjects of the study were 125 persons ( 72 males and 53 females) aged 20 - 60 years. The measurement of anthropometry was using an electronic digital scale for weight, microtoise for height, and meter line for waist circumference. In analysing body composition such as total body fat and visceral fat, we were using Bioelectrical Impendence Analyzer (BIA) Body Composition Monitor Omron Karada Scan HBF-375. Blood pressure was measured by an automatic blood pressure monitor OMRON HEM-7120. Hypertension was classified if the blood pressure of systolic $\geq 140$ and diastolic $\geq 90$. The association between risk factors variables and hypertension status was analysed by chi-square test and multiple logistic regression.

Results: The prevalence of hypertension was found $18.6 \%$ in male and $13.21 \%$ in female. All risk factors were similar between male and female ( $>>0.05)$. Body mass index (BMI), waist to hip ratio (WHtR), and total body fat were not statistically significant with hypertension status $(p>0.05)$. The statistically significant risk factors of hypertension only found in waist circumference and visceral fat $(p=0.036 ; p=0.002)$. Results of multivariate analysis, visceral fat remains significant in predicting hypertension, with 4.87 times higher risk of having hypertension in workers if having high visceral fat (95\% Cl 1.722-13.7831)

Applications/Originality/Value: This study shows that the prevalence of pre-hypertension and hypertension among workers were high. Thus, controlling modifiable risk factors is very important. Maintain the waist circumference and visceral fat in normal range with proper healthy lifestyle were needed especially in office workers.

Keywords: hypertension, office workers, body mass index, visceral fat, waist circumference

\section{INTRODUCTION}

Hypertension is a health problem that has an impact on various diseases. High blood pressure was associated with increased risks of all-cause mortality, Chronic Heart Disease (CHD), stroke, and kidney disease (1). The prevalence of hypertension has continued to increase over the past few years, including in Indonesia (2). Nowadays, hypertension has occurred not only in the elderly but also in younger age and sometimes undetectable, except for people who routinely checked their health status.

Office workers are one of the populations vulnerable to hypertension. Working patterns that sit more increase the risk of obesity. Based on the results of research, workers who sit more than 6 hours per day on risk for obesity compared to those who sit less than 45 minutes per day (3). Higher prevalence of over-nutrition can impact to financial loss of the institution because of higher health cost spending, absenteeism, work hours lost, and worker loss $(4,5)$.
Monitoring health status by weighing frequently was one of the principal messages for Indonesian's Nutrition Balance Guideline 2014. Based on weighing, we can assess body mass index which was one of the risk factors of hypertension. However, there was another anthropometric measurement who were closely related to hypertension, such as the measurements of waist circumference and waist ho height ratio (WHtR) (6-8). Limitation of anthropometric measurement was it can't distinguish between weight of fat mass and fat-free mass in overall body weight. Moreover, some research also showed that hypertension was also determined by the amount of fat inside the human body (9).

Some of the previous research showed varying result of hypertension risk factors and not specific for workers population $(10,11)$. In this study, we would investigate which indicators of anthropometric and body composition measurement that predict hypertension in workers. We also would analyse which factors that become the strongest predictors of hypertension in workers. Thus, it can be the 
reference indicators to prevent and controlling hypertension among workers.

\section{METHODS}

\section{Study Design}

This study was an observational study with a crosssectional design. This study was conducted in Universitas Ahmad Dahlan (UAD) Yogyakarta, Indonesian in April - May 2019. This study had already obtained ethical approval from the Research Ethics Committee of Universitas Ahmad Dahlan No: 011904021.

\section{Subjects}

The population of this study was all of the employees in all of UAD's campuses who work at least one year. We took sample in every unit of the university. The subjects were chosen by stratified random sampling method, thus it was able to represent the population of 5 campuses at UAD. The inclusion's criteria were not contract employee, not pregnant and breastfeed, and agree to took part the research with signing the informed consent which had been given before joined the research. Subjects were excluded if they reject to continue or not completely follow the procedure of the study.

\section{Study Protocols}

Data collection were obtained through questionnaire and direct measurement of anthropometric and body composition. Characteristics of subjects such as age, education level, marital status, working unit, and duration of work were obtained from the questionnaire. Anthropometric measurements in this study were height, weight and waist circumference. Height measurements used a microtoise attached on a flat wall, then the research subjects attach the back of the body namely the heel, calf, buttocks, back, and back of the head just below the measuring instrument in an upright position. Bodyweight measurements using digital scales are done with minimal clothing and do not carry objects that can add weight and in an upright position and foresight. Waist circumference measurements are carried out with a meter line. The subject uses thin clothing. The subject stands tall. The measurement faces the subject by placing the waist circumference meter line on the smallest part horizontally. Measurement of body composition using the Bioelectrical Impendence Analyzer (BIA) Body Composition Monitor Omron Karada Scan HBF-375. First, the BIA device is turned on then enter age, weight, height, and gender. The subject stands on the BIA tool. Measurement of blood pressure with an automatic blood pressure monitor OMRON HEM-7120. The subject sits quietly, upright, and feet tread on the floor.

\section{Statistical Analysis}

Characteristics of subjects (age, education level working duration, working unit, marital status, family history of hypertension) were categorized by sex and analysed by chisquare test by sex categorization. Result of weight and height measurement was calculated by divided weight by squared height $\left(\mathrm{kg} / \mathrm{m}^{2}\right)$ to obtain the body mass index (BMI). Nutrition status was categorized from BMI into 4 categories based on Indonesian's classification: underweight (<18.5), normal (18.525.0), overweight (25.1-27.0), and obesity (>27) Waist circumference was classified into normal if in female $\leq 80 \mathrm{~cm}$, male $\leq 90 \mathrm{~cm}$ and at risk if female $>80 \mathrm{~cm}$, male $>90 \mathrm{~cm}$. Waistto-height-ratio (WHtR) was calculated by divide waist circumference by height and categorized low risk if WHtR $<0.5$ and high risk if $W H t R \geq 0.5$ (8). Total body fat was categorized into 4 categories: low, normal, high, and very high. Visceral fat was categorized into 3 categories: normal (0.5-9.5), high (1014.5), and very high (15-30). Blood pressure measurement divided into 4 categories based on Joint National Committee VII: normal $(<120 /<80)$, prehypertension (120-139/80-89), stage 1 hypertension (140-159/90-99), and stage 2 hypertension $(\geq 160 / \geq 100)(12)$.

All data was collected at MS Excel and analysed with Statistical Program Stata 12. Categorical data were analysed by chi-square test and presented with significance $p<0.05$. Some data that was qualified to enter the multivariate analysis were analysed in multivariate logistic analysis. The data was presented in the table with Beta, $\mathrm{p}$, and odds ratio (OR) with $95 \%$ Confidence Interval $(95 \% \mathrm{Cl})$.

\section{RESULTS}

\section{Participants Characteristics}

Characteristics of subjects were presented in Table 1 . Total subjects of this study were 125 people ( 72 male and 53 female).

Table 1. Subjects characteristics

\begin{tabular}{|c|c|c|c|}
\hline Variables & $\begin{array}{l}\text { Male } \\
\mathrm{n}(\%)\end{array}$ & $\begin{array}{c}\text { Female } \\
\text { n (\%) }\end{array}$ & $\mathbf{p}$ \\
\hline \multicolumn{4}{|l|}{ Age (years old) } \\
\hline$\leq 40$ & $42(56.76)$ & $32(43.24)$ & 0.818 \\
\hline$>40$ & $30(58.82)$ & $21(41.18)$ & \\
\hline \multicolumn{4}{|l|}{ Marital status } \\
\hline Single & $9(42.86)$ & $12(57.14)$ & 0.134 \\
\hline Married & $63(60.58)$ & $41(39.42)$ & \\
\hline \multicolumn{4}{|l|}{ Education } \\
\hline <Diploma/Bachelor & $26(65.00)$ & $39(45.88)$ & 0.251 \\
\hline$\geq$ Diploma/Bachelor & $46(54.12)$ & $39(45.88)$ & \\
\hline \multicolumn{4}{|l|}{ Family history of hypertension } \\
\hline No & $60(56.07)$ & $47(43.93)$ & 0.400 \\
\hline Yes & $12(66.67)$ & $6(33.33)$ & \\
\hline \multicolumn{4}{|l|}{ Work duration } \\
\hline$\leq 40$ hours/week & $48(53.93)$ & $41(46.07)$ & 0.192 \\
\hline$>40$ hours/ week & $24(66.67)$ & $12(33.33)$ & \\
\hline
\end{tabular}

* statistically significant $(p<0.05)$ 
Table 1 (continued). Subjects characteristics

\begin{tabular}{|c|c|c|c|}
\hline Variables & $\begin{array}{l}\text { Male } \\
\text { n (\%) }\end{array}$ & $\begin{array}{c}\text { Female } \\
\text { n (\%) }\end{array}$ & $\mathbf{p}$ \\
\hline \multicolumn{4}{|l|}{ Body Mass Index (kg/m²) } \\
\hline Underweight $(<18.5)$ & $1(25.00)$ & $3(75.00)$ & 0.347 \\
\hline Normal (18.5-25) & $31(56.36)$ & $24(43.64)$ & \\
\hline Overweight (25.1-27) & $29(56.86)$ & $22(43.14)$ & \\
\hline Obesity (>27) & $11(73.33)$ & $4(26.67)$ & \\
\hline \multicolumn{4}{|l|}{ Waist circumference $(\mathrm{cm})$} \\
\hline Normal ( $\leq 90$ male, $\leq 80$ female) & 34 (58.62) & $24(41.38)$ & 0.830 \\
\hline Risk ( $>90$ male, $>80$ female) & $38(56.72)$ & $29(43.28)$ & \\
\hline \multicolumn{4}{|l|}{ Waist to Hip Ratio (WHtR) } \\
\hline Normal $(<0.5)$ & $15(50.00)$ & $15(50.00)$ & 0.334 \\
\hline High $(\geq 0.5)$ & $57(60.00)$ & $38(40.00)$ & \\
\hline \multicolumn{4}{|l|}{ Total body fat (\%) } \\
\hline Low & $1(50.00)$ & $1(50.00)$ & 0.432 \\
\hline Normal & $15(46.88)$ & $17(53.13)$ & \\
\hline High & $32(65.31)$ & $17(34.69)$ & \\
\hline Very high & $24(57.14)$ & $18(42.86)$ & \\
\hline \multicolumn{4}{|l|}{ Visceral fat } \\
\hline Normal (0.5-9.5) & $34(45.33)$ & $41(54.67)$ & $0.002^{*}$ \\
\hline High (10-14.5) & $24(70.59)$ & $10(29.41)$ & \\
\hline Very high (15-30) & $14(87.50)$ & $2(12.50)$ & \\
\hline \multicolumn{4}{|l|}{ Hypertension (mm/Hg) } \\
\hline Normal $(<120 /<80)$ & $32(53.33)$ & $28(46.67)$ & 0.367 \\
\hline Prehypertension (120-139/ 80-89) & $27(60.00)$ & $18(40.00)$ & \\
\hline Stage 1 hypertension (140-159/90-99) & $10(76.92)$ & $4(57.14)$ & \\
\hline Stage 2 hypertension $(\geq 160 / \geq 100)$ & $3(42.86)$ & $4(57.14)$ & \\
\hline
\end{tabular}

Table 2. Association risk factors of hypertension

\begin{tabular}{|c|c|c|c|}
\hline Variables & $\begin{array}{c}\text { Non-hypertension } \\
\mathrm{n}(\%)\end{array}$ & $\begin{array}{c}\text { Hypertension } \\
\mathrm{n}(\%)\end{array}$ & $\mathbf{p}$ \\
\hline \multicolumn{4}{|l|}{ Sex } \\
\hline Male & $59(81.94)$ & $13(18.06)$ & 0.465 \\
\hline Female & $46(86.79)$ & $7(13.21)$ & \\
\hline \multicolumn{4}{|l|}{ Age (years old) } \\
\hline$\leq 40$ & $61(82.43)$ & $13(17.57)$ & 0.565 \\
\hline$>40$ & $44(86.27)$ & $7(13.73)$ & \\
\hline \multicolumn{4}{|l|}{ Duration of work } \\
\hline$\leq 40$ hours/week & $73(82.02)$ & $16(17.98)$ & 0.343 \\
\hline$>40$ hours/week & $31(86.89)$ & $4(11.11)$ & \\
\hline \multicolumn{4}{|l|}{ Body Mass Index $\left(\mathrm{kg} / \mathrm{m}^{2}\right)$} \\
\hline Normal $(\leq 25)$ & $49(81.67)$ & $11(18.33)$ & 0.494 \\
\hline Overweight $(>25)$ & $56(86.15)$ & $9(13.85)$ & \\
\hline \multicolumn{4}{|l|}{ Waist circumference } \\
\hline Normal ( $\leq 90$ male, $\leq 80$ female) & $53(91.38)$ & $5(8.62)$ & $0.036^{\star}$ \\
\hline At risk (>90 male, $>80$ female) & $52(77.61)$ & $15(22.39)$ & \\
\hline \multicolumn{4}{|l|}{ Waist to Height Ratio (WHtR) } \\
\hline$<0.5$ & $26(86.67)$ & $4(13.33)$ & 0.648 \\
\hline$\geq 0.5$ & $79(83.16)$ & $16(16.84)$ & \\
\hline \multicolumn{4}{|l|}{ Total body fat (\%) } \\
\hline Normal & $32(94.12)$ & $2(5.88)$ & 0.059 \\
\hline High & $73(80.22)$ & $18(19.78)$ & \\
\hline \multicolumn{4}{|l|}{ Visceral fat } \\
\hline Normal & $71(92.21)$ & $6(7.79)$ & $0.002^{\star}$ \\
\hline High & $34(70.83)$ & $14(29.17)$ & \\
\hline
\end{tabular}

Mostly of subjects are aged $\leq 40$, married, and education level minimal diploma $(p>0.05)$. Family history of hypertension and work duration $>40$ hours/week higher in male subjects $(66.67 \%)$ than in female $(33.33 \%)$ and not differ between groups $(p>0.05)$. Result of anthropometric and body composition measurement showed that in male employee the number of over nutrition higher in male than female (overweight $56.86 \%$ and obesity $73.33 \%$ ). Higher risk of cardiovascular disease based on waist circumference and WHtR also higher in male ( $56.72 \%$ and $60.00 \%)$. Total body fat also higher in male, so do the visceral fat which was significantly different between male and female $(p=0.002)$.

\section{Risk Factors of Hypertension}

Association of risk factors was shown in Table 2. Based on research there were two variables that risk factors for 
Table 3. Multivariate analysis of hypertension's risk factors

\begin{tabular}{ccccccc}
\hline \multirow{2}{*}{ Variables } & \multicolumn{3}{c}{ Model 1 } & \multicolumn{2}{c}{ Model 2 } \\
\cline { 2 - 6 } & B & P & OR (95\% CI) & B & P & - \\
\hline BMI & -0.360 & 0.485 & $0.697(0.253-1.918)$ & - & - & - \\
\hline Waist circumference & 0.587 & 0.333 & $1.799(0.548-5.903)$ & - & - & - \\
\hline Total body fat & 0.400 & 0.650 & $1.491(0.265-8.395)$ & - & 1.584 & 0.003 \\
\hline Visceral fat & 1.260 & 0.036 & $3.525(1.084-11.461)$ & $4.872(1.722-13-7831)$ &
\end{tabular}

hypertension. Waist circumference and visceral fat were significantly associated with hypertension ( $p=0.036$ and $p=0.002$ ). Gender, age, duration of work, BMI, total body fat were not significantly associated with hypertension ( $p>0.05)$.

In Table $\mathbf{3}$ was shown the result of multivariate analysis. BMI, waist circumference, total body fat, and visceral fat were analyzed in multivariate analysis. BMI, waist circumference, and total body fat that has a value of $p>0.05$ then eliminated. Furthermore, the analysis was carried out on visceral fat and the p-value was 0.003 , which means that visceral fat was significantly related to hypertension.

\section{DISCUSSION}

Office workers have high-risk of overnutrition (overweight and obesity) as one of the risk factors of hypertension because of the higher rate of sit hours and long working hours in the workplace. In most cases, workers had long sitting hours as much as 3 hours/day in average and higher sitting hours related to higher BMI $(3,13,14)$. Beside of BMI, the other indicators of over nutrition that was related to hypertension were waist circumference, waist to hip ratio (WHR), waist to height ratio (WHtR), and body composition such as total body fat (TBF) and visceral fat (VF)) (6-9).

The findings of this research that the prevalence of normotension were $53.33 \%$ in male and $46.67 \%$ in female and the remaining were pre-hypertension and hypertension. It means that almost half of the respondent is pre-hypertension and hypertension with the prevalence of pre-hypertension higher than hypertension. These findings were similar with Mannocci (15) who also found that prevalence of prehypertension in age $<45$ years was $61.6 \%$ and at the older age the prevalence of pre-hypertension were lower, but increase in the prevalence of hypertension. Higher prevalence of hypertension in male than in the older group was the same as the finding of subjects adults in Bangladeshi whether in the rural or urban area (16).

Variables that statistically significant with hypertension among workers were only waist circumference and visceral fat. We found that age, sex, work duration, WHtR, and total body fat were not related to hypertension. These results were different with other research that found that higher BMI, WHR and total body fat had a strong association with hypertension in mining workers $(6,17)$. The difference of the findings because in our study we are different condition in workers, characteristics of body composition, or there were other better indicator such as the research of Oh et al. (18) in Korea that found other indicators that could predict hypertension and other metabolic risk factors better in normal waist circumference called visceral-to-subcutaneous fat ratio (VSR). There was also, hypertension strongly affected by another risk factors such as nutrition intake especially sodium intake had higher impact to blood pressure than another risk factors because more than half of Indonesian people $(52.7 \%)$ are categorized as high sodium intake as described as sodium intake $>2000 \mathrm{mg} /$ day (19). High sodium intake increases the incidence of hypertension than other factors based on a cohort study in Indonesia (20).

The risk factor of hypertension which was statistically significant was waist circumference and visceral fat. After continued to multivariate analysis, visceral fat was found as the strongest predictor of hypertension in workers. These findings were similar to another study that also found that visceral fat consistently impacts to hypertension $(10,18)$. We can conclude that among workers in this study, visceral fat was the independent determinant of hypertension. This finding similar to other research (21).

Effect of high visceral fat in increasing the risk of hypertension was explained in some research. Sironi et al. (22) stated that early hypertension was correlated with visceral fat. In the Chinese population, visceral fat correlated consistently with hypertension (10).

From the previous research, higher blood pressure was found in subjects with overfeeding diet and correlated with visceral fat only, even though there were body weight and body fat change (23). The change of blood pressure was controlled by the sympathetic nervous system (SNS) and kidney's regulation by the renin-angiotensin system (RAS). Visceral fat synthesis in the human body can make the amount of angiotensinogen increase that activates RAS and increase the amount of angiotensin II which impacted to adipocytes dysfunction, higher leptin and lower adiponectin, then activate SNS (24).

The limitation of his study was not analysing the nutrition intake that also important as a risk factor of hypertension. A comprehensive discussion would be better if enough data provided to identify modifiable factors to prevent hypertension in workers. Further study needed to explain and identify correlation another risk of hypertension in workers like prospective study.

\section{CONCLUSION}

In conclusion, our study showed that the prevalence of prehypertension and hypertension were high because almost half of the workers have blood pressure's category above normal. Risk factors of hypertension in workers were high waist circumference and high visceral fat. The strongest association was found in the relation of visceral fat and hypertension. Both of the risk factors were modifiable, so it was needed some intervention to control in a normal range. By controlling these risk factors, the risk of hypertension and the following disease also reduce. Thus, the quality of life and productivity in the workplace would increase and lower the burden of worker's institution. 


\section{ACKNOWLEDGEMENT}

We thank to Institute of research and community services Universitas Ahmad Dahlan that funded this research. The authors have no conflict of interest.

\section{REFERENCES}

1. Gosmanova EO, Mikkelsen MK, Molnar MZ, Lu JL, Yessayan LT, et al. Association of Systolic Blood Pressure Variability With Mortality, Coronary Heart Disease, Stroke, and Renal Disease. Journal of the American College of Cardiology, 2016;68(13):1375-86. https://doi.org/10.1016/j.jacc.2016.06. 054 PMid:27659458 PMCid:PMC5117818

2. Departemen Kesehatan Republik Indonesia. Laporan Hasil Riset Kesehatan Dasar (RISKESDAS) 2013. Jakarta. 2013.

3. Mummery WK, Schofield GM, Steele R, Eakin EG, Brown WJ. Occupational Sitting Time and Overweight and Obesity in Australian Workers, 2005;29(2):91-7. https://doi.org/10. 1016/j.amepre.2005.04.003 PMid:16005804

4. van Duijvenbode DC, Hoozemans MJ, van Poppel MN, Proper $\mathrm{KI}$. The relationship between overweight and obesity, and sick leave: a systematic review. International Journal of Obesity, 2009;33(8):807-16. https://doi.org/ 10.1038/ijo.2009.121 PMid:19528969

5. Østbye T, Dement JM, Krause KM. Obesity and Workers' Compensation. Arch Intern Med, 2007;167:766-73. https://doi.org/10.1001/archinte.167.8.766 PMid:17452538

6. De Oliveira CM, Ulbrich AZ, Neves FS, Dias FAL, Horimoto ARVR, Krieger JE, et al. Association between anthropometric indicators of adiposity and hypertension in a Brazilian population: Baependi Heart Study. PLoS ONE, 2017;12(10):1-10. https://doi.org/10.1371/journal.pone.01 85225 PMid:29023455 PMCid:PMC5638240

7. Van Den Munckhof ICL, Holewijn S, De Graaf J, Rutten JHW. Sex differences in fat distribution influence the association between BMI and arterial stiffness. Journal of Hypertension, 2017;35(6):1219-25. https://doi.org/10.1097/HJH.00000000 00001297 PMid:28441693

8. Yoo EG. Waist-to-height ratio as a screening tool for obesity and cardiometabolic risk. Korean Journal of Pediatrics, 2016;59(11):425-31. https://doi.org/10.3345/kjp.2016.59. 11.425 PMid:27895689 PMCid:PMC5118501

9. Neeland IJ, Turer AT, Ayers CR, Berry JD, Rohatgi A, Das S, et al. Body fat distribution and incident cardiovascular disease in obese adults. Journal of the American College of Cardiology, 2015;65(19):2150-1. https://doi.org/10.1016/ j.jacc.2015.01.061 PMid:25975481 PMCid:PMC4890465

10.Jiang J, Deng S, Chen Y, Liang S, Ma N, Xu Y, et al. Comparison of visceral and body fat indices and anthropometric measures in relation to untreated hypertension by age and gender among Chinese. International Journal of Cardiology, 2016;219:204-11. https://doi.org/10.1016/j.ijcard.2016.06.032 PMid:27327508

11.Wang Z, Zeng X, Chen Z, Wang X, Zhang L, Zhu M, Yi D. Association of visceral and total body fat with hypertension and prehypertension in a middle-aged Chinese population. Journal of Hypertension, 2015;33(8):1555-62. https:// doi.org/10.1097/HJH.0000000000000602 PMid:26103127

12. Martin J. The JNC 7 Hypertension Guidelines. The Journal of Lancaster General Hospital, 2008;3(3):91-7. https:// doi.org/10.1001/jama.290.10.1312-c PMid:12966114
13.Addo PNO, Nyarko KM, Sackey SO, Akweongo P, Sarfo B. Prevalence of obesity and overweight and associated factors among financial institution workers in Accra Metropolis, Ghana: a cross sectional study. BMC Research Notes, 2015;8(599):1-8. https://doi.org/10.1186/s13104-0151590-1 PMid:26499885 PMCid:PMC4619450

14.Proper KI, Hildebrandt VH. Overweight and obesity among Dutch workers: differences between occupational groups and sectors. International Archives of Occupational and Environmental Health, 2010;83(1):61-8. https:/doi.org/ 10.1007/s00420-009-0438-1 PMid:19506894

15. Mannocci A, Pignalosa S, Saulle R, Sernia S, et al. Prevalence of major cardiovascular risk factors among oil and gas and energy company workers. Annali Dell'Istituto Superiore Di Sanità, 2015;51(2):148-53. https://doi.org/10.4415/ANN

16. Rahman M, Zaman MM, Islam JY, Chowdhury J, Ahsan HN, et al. Prevalence, treatment patterns, and risk factors of hypertension and pre-hypertension among Bangladeshi adults. Journal of Human Hypertension, 2018;32(5):334-8. https://doi.org/10.1038/s41371-017-0018-x PMid:29230005 PMCid:PMC5860750

17.Afoakwah AN, Owusu WB. The relationship between dietary intake, body composition and blood pressure in male adult miners in Ghana. Asian Journal of Clinical Nutrition, 2011;3(1):1-13. https://doi.org/10.3923/ajcn.2011.1.13

18.Oh $\mathrm{YH}$, Moon JH, Kim HJ, Kong MH. Visceral-tosubcutaneous fat ratio as a predictor of the multiple metabolic risk factors for subjects with normal waist circumference in Korea. Diabetes, Metabolic Syndrome and Obesity: Targets and Therapy, 2017;10:505-11. https://doi.org/10.2147/DMSO.S150914ＰMid:29270027 PMCid:PMC5729827

19.Prihatini S, Permaesih D, Julianti ED. Asupan Natrium Penduduk Indonesia: Analisis Data Survei Konsumsi Makanan Individu (SKMI) 2014. Gizi Indonesia, 2017;39(1):15-24. https://doi.org/10.36457/gizindo.v39i1. 205

20. Rahajeng E, Kristanti D, Kusumawardani N. Perbedaan Laju Kecepatan Terjadinya Hipertensi Menurut Konsumsi Natrium [Studi Kohort Prospektif Di Kota Bogor, Jawa Barat, Indonesia] (the Incidence Rate Difference of Hypertension According To Sodium Consumption [a Prospective Cohort Study in Bogor Cit. Penelitian Gizi Dan Makanan (The Journal of Nutrition and Food Research), 2017;39(1):45-53. https://doi.org/10.22435/pgm.v39i1.5972.45-53

21. Faria AN, Ribeiro Filho FF, Ferreira SRG, Zanella MT. Impact of visceral fat on blood pressure and insulin sensitivity in hypertensive obese women. Obesity Research, 2002;10(12):1203-6. https://doi.org/10.1038/oby.2002.164 PMid:12490663

22.Sironi AM, Pingitore A, Ghione S, De Marchi D, Scattini B, Positano V, et al. Early hypertension is associated with reduced regional cardiac function, insulin resistance, epicardial, and visceral fat. Hypertension, 2008;51(2):282-8. https://doi.org/10.1161/HYPERTENSIONAHA.107.098640 PMid: 18172058

23. Covassin N, Sert-Kuniyoshi FH, Singh P, Romero-Corral A, et al. Experimental Weight Gain Increases Ambulatory Blood Pressure in Healthy Subjects: Implications of Visceral Fat Accumulation. Mayo Clinic Proceedings, 2018;93(5):618-26. https://doi.org/10.1016/j.mayocp.2017.12.012 
24.Raymond JL, Counch SC. Medical Nutrition Therapy for Cardiovascular Disease. In LK Mahan, JL Raymond (Eds.), Krause's Food \& The Nutrition Care Process (14th ed., pp. 646-680). St. Louis, Missouri: Elsevier. 2017. 